\title{
Feasibility of Type D Botulinum Toxin for Rodent Prevention and Control in Plateau Pastoral Areas
}

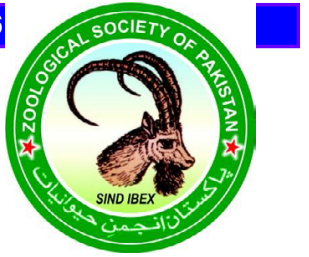

\author{
Li Shengqing 1,2,3, Zhang Xiyunn, 2,3 , Liu Shengcai ${ }^{2,3}$, Hu Guoyuan², Fan Yuxia' ${ }^{2}$, \\ Liu Huaixin ${ }^{2}$, Wang Tingting ${ }^{2}$ and Zhang Yanming ${ }^{1 *}$ \\ ${ }^{1}$ College of Veterinary Medicine, Northwest Agriculture and Forestry University, Yang \\ Ling, 712100, China \\ ${ }^{2}$ Qinghai Academy of Animal Sciences and Veterinary Medicine, Xining, 810016, China \\ ${ }^{3}$ State Key Laboratory of Plateau Ecology and Agriculture, Qinghai University, Xining, \\ 810016, China
}

\begin{abstract}
A B S T R A C T
This work aims to explore the feasibility of using type D botulinum toxin as a novel, environmentally friendly biological rodenticide for the population control of rodents in plateau pastoral area. The toxin is subjected to toxin component, DNA sequencing, and bioinformatic analyses. The lethal median dose $\left(\mathrm{LD}_{50}\right)$ values of intragastrically and orally administred type $\mathrm{D}$ botulinum toxin in wild plateau pikas, plateau zokors, and Microtus fuscus are calculated through Horn's method and the improved Karber method. The ability of the toxin to prevent and control rodent damage is assessed through plot experiments. The safety of type D botulinum toxin toward nontarget animals, such as yaks, Tibetan sheep, dogs, vultures, and birds, is also tested. Results show that the toxin is encoded by a type D botulinum neurotoxin gene. The DNA and amino acid sequences of the full neurotoxin gene comprise 3831 base pairs and 1276 amino acid residues, respectively. The nucleic acid and protein sequences of the toxin exhibits $99 \%$ homology with those of a known type D botulinum neurotoxin gene, and the composition of the functional domain of the toxin is consistent with that of type $\mathrm{D}$ botulinum neurotoxin. For plateau pikas and plateau zokors, the $\mathrm{LD}_{50}$ values of intragastrically administered type $\mathrm{D}$ botulinum toxin is 6810 and $5840 \mathrm{MLD} / \mathrm{kg}$ weight, respectively, and those of orally administered type D botulinum are 1.231 and $1.319 \mathrm{~g} / \mathrm{kg}$ weight, respectively. The natural enemies of rodents are strongly resistant to type D botulinum toxin. Experimental results indicate that type D botulinum toxin can be used as a new biological rodenticide for the prevention and control of rodent damage in plateau pastoral area.
\end{abstract}

\begin{tabular}{l} 
Article Information \\
\hline Received 26 December 2018 \\
Revised 22 May 2019 \\
Accepted 17 September 2019 \\
Available online 04 June 2021 \\
Authors' Contribution \\
\hline L Shengqing and ZX wrote the man- \\
uscript. L Shengcai, HG analyzed the \\
data. FY, LH and WT contributed to \\
sampling and laboratory experiments. \\
ZY designed the study. \\
Key words \\
\hline $\begin{array}{l}\text { Type D Botulinum neurotoxin, } \\
\text { Bioinformatic identification, } \text { LD }_{50}, \\
\text { Target animal sensitivity, Safety } \\
\text { of non-target animals, Regional } \\
\text { prevention and control test }\end{array}$
\end{tabular}

\section{INTRODUCTION}

Q inghai is the source area of the Yangtze, Yellow, and Lancang Rivers. It is located in the hinterland of the Qinghai-Tibet Plateau and is an important water conservation area in China. In fact, it is also known as the Three Rivers Source and is designated by Chinese ecologists as the Water Tower of China. The protection of Qinghai is crucial for the sustainable development of the social economy and ecological security of the middle and lower reaches of the Yangtze, Yellow, and Lancang Rivers (Zhou et al., 2002).

In recent years, grasslands have become increasingly degraded with global climate change, artificial overloading, and overgrazing. Some areas of Qinghai exhibit reverse vegetation succession, secondary bare land, and serious desertification. Small-sized herbivores, such as rodents and lagomorpha (namely, rodents in a broad sense), are important

\footnotetext{
* Corresponding author: zhangym@nwsuaf.edu.cn 0030-9923/2021/0004-1449 \$9.00/0

Copyright 2021 Zoological Society of Pakistan
}

primary consumers in the Qinghai alpine ecosystem. In the absence of the interference of human factors, these herbivores participate in maintaining ecosystem stability. However, when their population growth exceeds a certain limit, they pose an environmental hazard in the form of rodent damage. The main species of rodents in Qinghai Province are plateau pikas and plateau zokors. The average area under threat of extensive rodent damage per year is 9.717 million $\mathrm{hm}^{2}$ (Zhang et al., 2001), and the area that is actually damaged by rodents is 7.3615 million $\mathrm{hm}^{2}$. Rodent damage results in the loss of more than 13.884 billion $\mathrm{kg}$ of fresh forage grass each year. Given that this volume of grass can be used to raise an additional 9.5096 million sheep, the ensuing economic loss caused by rodent damage reaches as high as 2.852 billion yuan. The area with rodent damage in Qinghai is 6.444 million $\mathrm{hm}^{2}$. The area of severely degraded grassland with vegetation coverage of less than $15 \%$ has reached $2.0921 \mathrm{hm}^{2}$. The occurrence of rodent damage accelerates the degradation of grasslands, the formation of secondary bare lands, and the desertification of soils. Therefore, the prevention and control of rodent populations in areas with severe rodent 
damage is necessary.

At present, the chemical method and the biological method are commonly used for the large-scale prevention and control of rodent damage. Given the disadvantages of chemical rodenticides in practice, such as persistence and toxicity to humans, livestock, and natural rodent enemies (Zhong and Fan, 2002), the development of a novel biological rodenticide that is environmentally friendly and effectively controls the population density of rodents at high altitudes is imperative.

Seven types of toxins, A, B, C, D, E, F, and G, have been derived from Bacillus botulinus since it was first isolated in 1897 (Peter et al., 1986). Type D causes cases of bovine and mutton toxicosis in Africa, North America, and Australia. In China, only two cases of the isolation of type D C. botulinus toxin have been reported. One strain was isolated from sea mud from the East China Sea (Wang, 1987), and the other $\left(\mathrm{D}_{8901}\right.$ strain) was isolated by this laboratory from sick sheep (Zhang et al., 1990). Numerous domestic and international studies on Clostridium botulinum have been performed. However, these studies have mainly focused on the structural characterization of neurotoxins (Kathryn, 2002; Hanson, 2000; Gessler, 1999; Hallis, 1996). Several works have investigated the mechanism and treatment of tetrodotoxin poisoning (Cedric et al., 2013; Christian et al., 2013). Most works have concentrated on the use of type A botulinum toxin to treat cosmetic diseases. However, the use of type $\mathrm{D} C$. botulinum toxin in the prevention and control of rodent damage has not yet been reported at home or abroad.

This work aims to explore the feasibility of using type D botulinum toxin as a novel, environmentally friendly biological rodenticide for the population control of rodents in a plateau pastoral area. The toxin is subjected to toxin component, DNA sequencing, and bioinformatic analyses. The lethal median dose $\left(\mathrm{LD}_{50}\right)$ values of intragastrically and orally administred type D botulinum toxin for wild plateau pikas, plateau zokors, and Microtus fuscus are calculated through Horn's method and the improved Karber method. The ability of the toxin to prevent and control rodent damage is assessed through plot experiments. The safety of type D botulinum toxin toward nontarget animals, such as yaks, Tibetan sheep, dogs, vultures, and birds, are also tested.

\section{MATERIALS AND METHODS}

Strain for testing

Type $\mathrm{D}_{8901}$ C. botulinus was provided by Botuline Laboratory, Veterinary Research Institute of the Academy of Veterinary Sciences, Qinghai University.
Drugs and reagents

Bacterial DNA Extraction Kit, DNA Rapid Purification Recovery Kit, Plasmid Extraction Kit (Shanghai Shenggong Biological Co., Ltd.).

\section{Laboratory animals}

Wild plateau pikas, plateau zokors, and M. fuscus were captured from field pastoral areas in Qilian, Gangcha, and Datong County of Qinghai, respectively. Gypaetus barbatus, black vultures, Aquila nipalensis, golden eagles, and owls were reared in Xining Zoo. Yaks, Tibetan sheep, and dogs were procured from a breeding farm in Huzhu County, Qinghai.

\section{Biological characteristics of type D C. botulinus toxin}

Type $\mathrm{D}_{8901}$ C. botulinum was dialyzed to a concentration of 20 million $\mathrm{MLD} / \mathrm{ml}$ toxin. Toxinelectrophoresis was conducted after precipitation with $20 \%-100 \%$ ammonium sulfate. A commercial bacterial DNA extraction kit was used to extract bacterial genomic DNA. Three pairs of primers for target fragment amplification were designed on the basis of with the gene sequence of type D botulinum toxin retrieved from GenBank (Table I).

\section{$P C R$ reaction system}

Comprised $2 \mu \mathrm{l}$ of template genomic DNA; $1 \mu \mathrm{l}$ each of upstream and downstream primers; $1 \mu \mathrm{l}$ of $4 \mathrm{mM} \mathrm{dNTP}$; $5 \mu \mathrm{l}$ of $10 \times$ PCR Buffer; $1 \mu \mathrm{l}$ of Taq DNA polymerase; and $10 \mu \mathrm{l}$ of $10 \times$ PCR Enhancer Solution. Water was added to bring the total volume of the reaction system to $50 \mu \mathrm{l}$. Reaction conditions: Amplification was conducted with 1 min of preheating at $95^{\circ} \mathrm{C}, 40 \mathrm{~s}$ of denaturation at $95^{\circ} \mathrm{C}$, $50 \mathrm{~s}$ of annealing at $55^{\circ} \mathrm{C}, 4 \mathrm{~min}$ of extension at $72{ }^{\circ} \mathrm{C}$ for 30 cycles, and finally, $10 \mathrm{~min}$ of extension at $72{ }^{\circ} \mathrm{C}$. To determine product size, amplicons were subjected to $1 \%$ agarose gel electrophoresis with DL2000 as a standard molecular weight.

DNA Rapid Purification Recovery Kit was used for PURIGENE recovery. The recovered DNA target fragments were mixed with pGEM-T plasmid vector in a 4:1 mole ratio with the addition of $1 \mu \mathrm{l}$ of $10 \times \mathrm{T} 4$ Ligase buffer and $1 \mu \mathrm{l}$ of T4 Ligase. Sterile double distilled water was added to bring the reaction system to a volume of $10 \mu \mathrm{l}$. Ligation was conducted for $14-16 \mathrm{~h}$ at $16{ }^{\circ} \mathrm{C}$. The ligation product was converted by Escherichia coli. A single white colony was collected for proliferation, and the plasmid was extracted for restriction enzyme digestion.

\section{DNA sequencing of type D botulinum toxin gene}

A commercial plasmid extraction kit was used to extract plasmids for use as templates for DNA sequencing with $\mathrm{T} 7$ and Sp6 primers. 
Table I. Gene amplification primers for type D botulinum toxin.

\begin{tabular}{lll}
\hline Number & Name & Primer sequence \\
\hline First pair of primers & 1F & $5^{\prime}$-ATGTTAGTATTATGACATGGCCAG-3' \\
& $1 \mathrm{R}$ & $5^{\prime}$-TTGTACATTAGTCTCATCTGTAA-3' \\
Second pair of primers & 2F & $5^{\prime}$-TTACAGATGAGACTAATGTACAA-3' \\
& 2R & $5^{\prime}$-ATTGTATTACTCTACCCATCCTGG-3' \\
Third pair of primers & $3 \mathrm{~F}$ & $5^{\prime}$-GGATTAAGATATCTAAAGATTTAAC-3' \\
& $3 \mathrm{R}$ & $5^{\prime}$-GTTAAATCTTTAGATATCTTAATCC-3' \\
\hline
\end{tabular}

Table II. LD $_{50}$ of intragastrically administered type D botulinum toxin in plateau pikas, plateau zokors, and $M$. fuscus.

\begin{tabular}{|c|c|c|c|c|c|c|c|c|}
\hline Rodent species & Group & $\begin{array}{l}\text { Number of } \\
\text { animals }\end{array}$ & $\begin{array}{l}\text { Dosage } \\
\text { (MLD/kg) }\end{array}$ & $\begin{array}{l}\text { Mean } \\
\text { weight (g) }\end{array}$ & $\begin{array}{l}\text { Mean intake of toxin } \\
\text { (MLD/1 animal) }\end{array}$ & $\begin{array}{l}\text { Death rate } \\
\text { (Number of animals) }\end{array}$ & Result & $\begin{array}{l}\mathrm{LD}_{50}(\mathrm{MLD} / \\
\mathrm{kg} \text { weight) }\end{array}$ \\
\hline \multirow[t]{4}{*}{ Plateau pika } & I & 5 & 2150 & 146.8 & 3139 & 0 & $0 / 5$ & 6810 \\
\hline & II & 5 & 4640 & 128.6 & 5939 & 1 & $1 / 5$ & \\
\hline & II & 5 & 10000 & 152.2 & 15200 & 4 & $4 / 5$ & \\
\hline & IV & 5 & 21500 & 131.8 & 28165 & 5 & $5 / 5$ & \\
\hline \multirow[t]{4}{*}{ Plateau zokor } & I & 5 & 2150 & 212.2 & 2279 & 0 & $0 / 5$ & 5840 \\
\hline & II & 5 & 4640 & 230.6 & 5336 & 3 & $3 / 5$ & \\
\hline & III & 5 & 10000 & 208.8 & 10400 & 3 & $3 / 5$ & \\
\hline & IV & 5 & 21500 & 254.6 & 27305 & 5 & $5 / 5$ & \\
\hline \multirow[t]{4}{*}{ Microtus fuscus } & I & 5 & 21500 & 29.24 & 31433 & 0 & $0 / 5$ & 50100 \\
\hline & II & 5 & 46400 & 24.72 & 57350 & 3 & $3 / 5$ & \\
\hline & III & 5 & 100000 & 27.92 & 139600 & 4 & $4 / 5$ & \\
\hline & IV & 5 & 215000 & 21.66 & 232845 & 5 & $5 / 5$ & \\
\hline
\end{tabular}

Table III. LD $_{50}$ of orally administered type D botulinum toxin in plateau pikas and plateau zokors.

\begin{tabular}{lllllllll}
\hline Rodent species & Group & $\begin{array}{l}\text { Dosage } \\
(\mathbf{g} / \mathbf{1 0 0} \mathbf{g})\end{array}$ & $\begin{array}{l}\text { Number of } \\
\text { animals }\end{array}$ & $\begin{array}{l}\text { Mean weight } \\
\mathbf{( g )}\end{array}$ & $\begin{array}{l}\text { Toxin } \\
\text { intake }\end{array}$ & $\begin{array}{l}\text { Death time } \\
\text { (h) }\end{array}$ & $\begin{array}{l}\text { Death } \\
\text { rate }\end{array}$ & $\begin{array}{l}\text { LD } \\
\text { (g//kg) }\end{array}$ \\
\hline Plateau pika & I & 0.4 & 5 & 128 & 2.048 & $24-120$ & $5 / 5$ & 1.231 \\
& II & 0.2 & 5 & 144 & 1.152 & $48-120$ & $5 / 5$ \\
& III & 0.1 & 5 & 138 & 0.552 & 72 & $1 / 5$ \\
Plateau zokor & IV & 0.05 & 5 & 141 & 0.282 & Survived & $0 / 5$ \\
& I & 2.0 & 5 & 146 & 0.146 & Survived & $0 / 5$ \\
& II & 1.0 & 5 & 234 & 9.36 & $76 \mathrm{~h}$ & $5 / 5$ & 1.319 \\
& III & 0.5 & 5 & 248.6 & 4.98 & $104 \mathrm{~h}$ & $2 / 5$ \\
& IV & 0.25 & 5 & 236.6 & 2.35 & $56 \mathrm{~h}$ & $3 / 5$ \\
& V & 0.125 & 5 & 316.6 & 1.59 & $168 \mathrm{~h}$ & $1 / 5$ \\
\hline
\end{tabular}


Analysis of type D C. botulinus gene

GENRUNNER or NCBI-BLAST (www.ncbi.nlm. nih.gov/blast) software was used to analyze restriction enzyme sites, encoded amino acid sequence, homology, and protein functional domain of the gene sequence.

Table IV. Safety of type D botulinum toxin to the natural enemies of rats in grasslands.

\begin{tabular}{lllll}
\hline Animal & $\begin{array}{l}\text { Mean } \\
\text { weight (kg) }\end{array}$ & \multicolumn{2}{c}{$\begin{array}{l}\text { Number } \\
\text { Toxin dose } \\
(\mathbf{1 0 , 0 0 0} \text { MLD) }\end{array}$} & Results \\
\hline $\begin{array}{l}\text { Gypaetus } \\
\text { barbatus }\end{array}$ & 6.0 & 5 & 60.0 & Survived \\
Black vulture & 3.0 & 5 & 75.0 & Survived \\
$\begin{array}{l}\text { Aquila } \\
\text { nipalensis }\end{array}$ & 1.5 & 5 & 37.5 & Survived \\
Golden eagle & 3.0 & 5 & 75.0 & Survived \\
Owls & 0.4 & 5 & 10.0 & Survived \\
\hline
\end{tabular}

$L D_{50}$ of intragastrically administered type D botulinum neurotoxin in plateau pikas, zokors and Microtus fuscus

The $\mathrm{LD}_{50}$ of intragastrically administered type D botulinum toxin was determined through Horn's method with four test groups. Each group received different concentrations of the toxin per $\mathrm{kg}$ body weight $(2,150$, $4,640,10,000$, and 21,500 MLD). A total of 20 wild plateau pikas and plateau zokors were randomly divided into four groups with five animals per group. The toxin was administered at the doses of $1 \mathrm{ml} / 100 \mathrm{~g}$ weight and $1 \mathrm{ml} / 200 \mathrm{~g}$ weight to plateau pikas and plateau zokors, respectively. The animals were observed for 10 days, and the symptoms were recorded.

Table V. Safety of type D botulinum toxin to the Non-target animal.

\begin{tabular}{llllll}
\hline Animal Mean- & $\begin{array}{l}\text { Num- Toxin dose } \\
\text { weight(kg) }\end{array}$ & $\begin{array}{l}\text { Toxin- } \\
\text { ber }\end{array}$ & Results \\
(MLD) & & & \\
MLD/kg & \\
\hline Yak & 166.0 & 5 & $8.3 \times 10^{9}$ & $>5.0 \times 10^{7}$ & Survived \\
Sheep & 21.0 & 5 & $8.7 \times 10^{8}$ & $4.22 \times 10^{6}$ & \\
Dog & 18.5 & 5 & $9.3 \times 108$ & $>5.0 \times 10^{7}$ & Survived \\
\hline
\end{tabular}

$L D_{50}$ of orally administered type $D$ botulinum neurotoxin in plateau pikas and plateau zokors

A total of 25 plateau pikas and 25 plateau zokors were captured, weighed, assigned to treatment groups, and reared in mouse cages. Plateau pikas were divided into five test groups in accordance with different bait dosages (0.4, $0.2,0.1,0.05,0.025 \mathrm{~g} / 100 \mathrm{~g}$ weight). Plateau zokors were also divided into five testing groups in accordance with different bait dosages $(2.0,1.0,0.5,0.25$ and $0.125 \mathrm{~g} / 200$ $\mathrm{g}$ weight). Normal feeding was resumed after the oral administration of the toxin. The animals were observed for seven days, and animal disease and death were recorded. The improved Karber method was used to calculate $\mathrm{LD}_{50}$ (the calculation method is appended).

Determination of the safety of type $D$ botulinum toxin to natural rat enemies

\section{G. barbatus}

Type D botulinum toxin was diluted 10-fold and injected in $25 \mathrm{~g}$ of beef at a dose of 0.10 million MLD $/ \mathrm{kg}$ weight (body weight was estimated at $6 \mathrm{~kg}$ ). The treated beef was fed to five G. barbatus at the dosage of 0.60 million $\mathrm{MLD} / \mathrm{g}$. barbatus. After 1 week of observation, two G. barbatus were continuously fed with the toxin at the dosage of 0.50 million MLD/kg weight. The animals were observed, and the results were recorded.

Black vultures, prairie carvings, gold carvings and owls

Type D botulinum toxin was diluted 10-fold and injected in $20 \mathrm{~g}$ of beef at the dose of 0.25 million MLD/ $\mathrm{kg}$ weight. The injected beef was fed to five black vultures, five prairie carvings, five gold carvings, and five owls. The animals were observed for seven days.

\section{Determination of the safety of type D botulinum toxin to yak, sheep and dog}

Ten million MLD/ml of botulinum toxin type D was administered to yak, sheep and dog according to their body weight. One week was observed, and the incidence and death of the experimental animals were recorded.

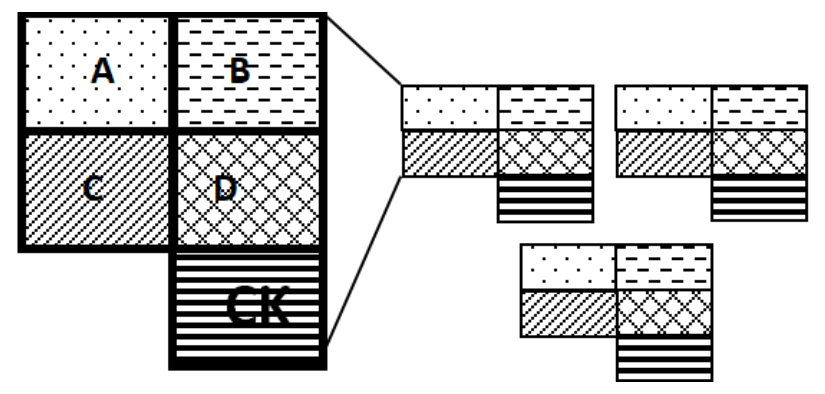

Fig. 1. Schematic of the plot test of type D botulinum toxin administration to plateau zokors; A, 20,000 MLD/g granular bait; B, 10,000 MLD/g barley bait; C, 15,000 $\mathrm{MLD} / \mathrm{g}$ barley bait; $\mathrm{D}, 20,000 \mathrm{MLD} / \mathrm{g}$ barley bait; $\mathrm{CK}, 50$ $\mathrm{m}$ isolation belt.

\section{Experimental quadrat samples}

Sample design

The test comprised five treatment groups: homemade 
botulinum toxin granular bait administered at 20,000 $\mathrm{MLD} / \mathrm{g}$; botulinum toxin barley bait administered at $10,000 \mathrm{MLD} / \mathrm{g}, 15,000 \mathrm{MLD} / \mathrm{g}$, and 20,000 MLD/g; and CK. Each plot area of $0.25 \mathrm{~m}^{2}(50 \mathrm{~m} \times 50 \mathrm{~m})$ had three replicates, and the groups were randomly arranged in the middle. The peripheries of the quadrats were surrounded by protection lines with widths of $50 \mathrm{~m}$ (Fig. 1).

For Survey of rat population density at the start of the experiment, all mounds in the plots were leveled, and data were recorded. After 2 days, red chopsticks were used to mark new mounds, data were recorded, and rat density in the experimentation area was calculated.

\section{Administration}

Caves were penetrated using feeding tools. Baits $(10-15 \mathrm{~g})$ with different toxin concentrations were placed in the holes. Caves were inspected 10 days after bait administration.

\section{RESULTS}

\section{Biological characteristics of type D C. botulinum toxin}

Basic components of type $D$ C. botulinum toxin

The $40 \%$ ammonium sulfate precipitate exhibited L and $\mathrm{M}$ toxin bands at 500-300 KDD. The $40 \%$ ammonium sulfate precipitate $+\beta$ mercaptoethanol electrophoresis bands exhibited NT-, NTNHA-, Hc-Lc-related, HA70, HA50, and HA33 bands at the corresponding molecular weight locations (Fig. 2).

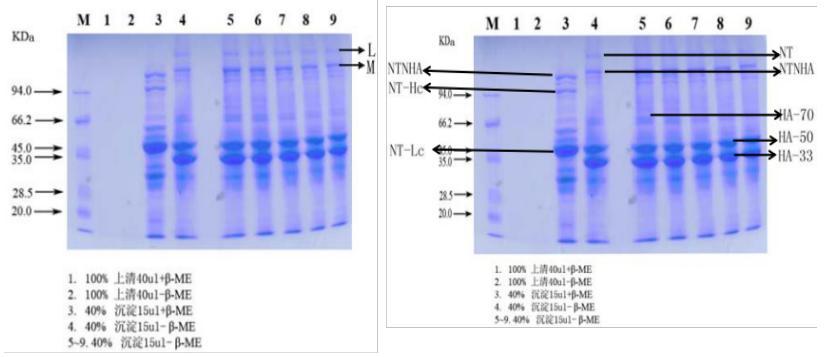

Fig. 2. SDS-PAGE results for the components of type D8901 botulinum in $40 \%$ ammonium sulfate. $1,100 \%$ supernatant $40 \mu 1+1+\beta-M E ; 2,100 \%$ supernatant $40 \mu 1$ - $\beta-M E$; $3,40 \%$ supernatant $15 \mu \mathrm{I}+\beta$-ME; $4,40 \%$ supernatant $15 \mu 1$ $\beta$-ME; $5-9,40 \%$ supernatant $15 \mu \mathrm{I}-\beta$-ME.

PCR amplification of type D botulinum toxin gene Three pairs of PCR amplification primers were designed in accordance with the type $\mathrm{D}$ botulinum toxin gene sequence retrieved from GenBank databases. Three DNA fragments with the expected sizes of $1450,2400 \mathrm{bp}$ were amplified (Fig. 3).

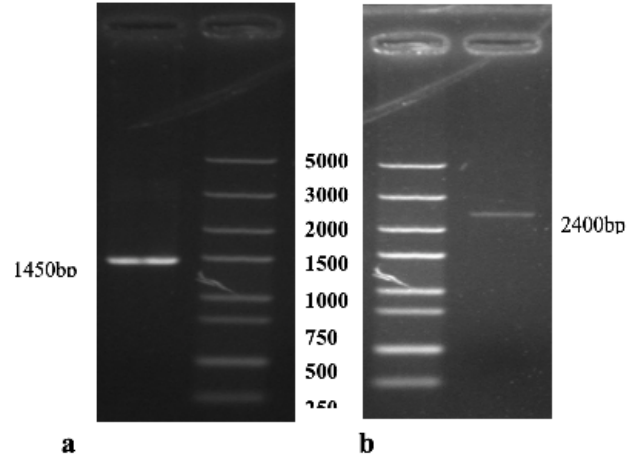

Fig. 3. Electrophoretic analysis of gene fragment of botulinum neurotoxin type D.

Gene cloning and identification of type D botulinum toxin

A PCR-amplified gene fragment was cloned into a pGEM-T vector to convert E. coli. A positive clone was obtained after preliminary blue-white screening. The clone was identified through further enzyme digestion, and the restriction enzyme sites of type $\mathrm{D}$ botulinum toxin were consistent (Fig. 4). Two kinds of clones, namely pGEM-BT1 and pGEM-BT2, were obtained. And then, two clones were subjected to DNA sequencing with T7 and Sp6 primers through the double direction method. The DNA sequence was obtained. Sequence splicing was performed with restriction enzymes and DNA sequence integration software to obtain the full sequence of the PCR-amplified fragment.
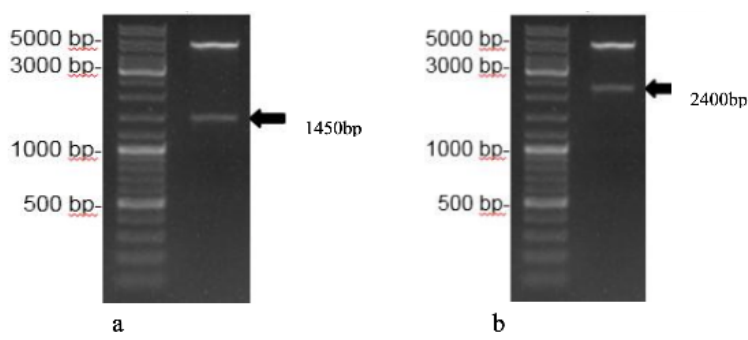

Fig. 4. (a) Plasmid identification after BT1 cloning, (b) Plasmid identification after BT2 cloning. BT1, light chain fragment; BT2, Heavy chain fragment.

Gene sequences and functional domain analysis of type D botulinum toxin

The obtained DNA encoded protein sequences were compared with sequences retrieved from GenBank database. The cloned DNA sequence was $99 \%$ homologous with the type D botulinum toxin gene and lacked base deletions or additions. The amino acid sequence of the encoded protein was only $52 \%$ homologous with that of 
type $\mathrm{C}$ botulinum toxin gene. Therefore, $\mathrm{PCR}$ amplification and cloning definitively identified the gene as type $\mathrm{D} C$. botulinum neurotoxin gene. The DNA sequence was 3831 $\mathrm{bp}$ in length. The amino acid sequence was 1276 amino acid bases in length. NCBI-Conserved Domain analysis shows that the functional domain composition of the encoded protein of the isolated gene is consistent with that of the botulinum toxin (Fig. 5).

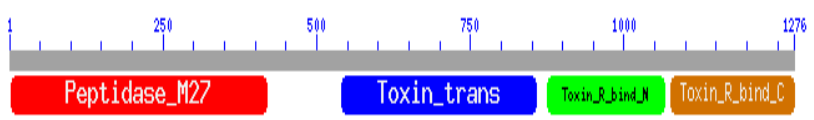

Fig. 5. Protein functional domain composition of botulinum toxin.

Toxicity of type D botulinum toxin toward grassland rodents

$L D_{50}$ of intragastrically administered type $D$ botulinum toxin in plateau pikas, plateau zokors and M. fuscus

The $\mathrm{LD}_{50}$ of intragastrically administered type $\mathrm{D}$ botulinum toxin in plateau pikas was $6,810 \mathrm{MLD} / \mathrm{kg}$ (95\% fiducial limit 4,410-10,500 MLD/kg). The $\mathrm{LD}_{50}$ of intragastrically administered type $\mathrm{D}$ botulinum toxin to M. fuscus was 0.0501 million MLD $/ \mathrm{kg} . \mathrm{w}$ (95\% fiducial limit $0.0308-0.0814$ million $\mathrm{MLD} / \mathrm{kg}$ ). The $\mathrm{LD}_{50}$ of intragastrically administered type $\mathrm{D}$ botulinum toxin in plateau zokors was $5840 \mathrm{MLD} / \mathrm{kg}$, (95\% fiducial limit 3,430-9,950 MLD/kg) (Table II).

$L D_{50}$ of orally administered type $D$ botulinum toxin in plateau pikas, plateau zokors, and $\mathrm{M}$. fuscus

The $\mathrm{LD}_{50}$ of type $\mathrm{D}$ botulinum rodenticide particles in plateau pikas and zokors was 1.231 and $1.319 \mathrm{~g} / \mathrm{kg}$ weight, respectively (Table III).

Safety of type D botulinum toxin to the natural rodent enemies

G. barbatus was fed with 0.50 million $\mathrm{MLD} / \mathrm{kg}$ weight type $\mathrm{D}$ botulinum toxin without any poisoning. Black vultures, A. nipalensis, and owls were fed with 0.25 million $\mathrm{MLD} / \mathrm{kg}$ weight type D botulinum toxin without any poisoning (Table IV). These results indicated that $G$. barbatus and other animals that are natural enemies of rodents are insensitive to the toxin. Thus, the application of type D botulinum as a rodenticide does not threaten the safety of the natural enemies of rodents.

Safety of type D botulinum toxin to the yak, sheep and dog The results showed that the dose of toxic poisoning of cattle and dogs was more than $5.0 \times 10^{7} \mathrm{MLD} / \mathrm{kg}$, and the dose of toxic poisoning of sheep was $4.2 \times 10^{6} \mathrm{MLD} / \mathrm{kg}$ (Table V). Combined with the maximum daily feed intake of cattle, sheep and dogs, it was determined that the above animals could not be fed so many poisoned baits at the rodent control site. so the experiment confirmed that this rodenticide is safe for non-target animals on the grassland.

Results of quadrat sampling experiment

The average killing effect of the botulinum toxin type D granule bait on zokors was $89.93 \%$. The average killing effect of the three different concentration groups $(0.10 \%$, $0.15 \%, 0.20 \%$ ) were $80.6 \%, 89.13 \%$ and $87.73 \%$, whereas the average reduction rate of the control group was $32.7 \%$. Type $\mathrm{D}$ botulinum toxin in the form of granular bait exhibited the best killing result (Table VI).

\section{DISCUSSION}

C. botulinum is an anaerobic Clostridium species that has the basic characteristics of this genus, that is, it is an Gram-positive anaerobic sporulating baculovirus. The spore is wider than the reproductive body and is spindle shaped. Botulinum toxins can inhibit breathing and cause death and are some of the most toxic naturally occurring toxins (Smith and Rusnak, 2007). In accordance with the antigenicity of the botulinum toxin, seven types of C. botulinum exist, namely A, B, C $(1,2), \mathrm{D}, \mathrm{E}, \mathrm{F}$, and G. Types A, B, and $\mathrm{E}$ are the main causes of poisoning. Types $\mathrm{C}$ and $\mathrm{D}$ are major animal and poultry pathogens. Types $F$ and $G$ are rarely isolated. No report exists on human poisoning caused by Type $G$ bacteria (Dembek et al., 2007; Schiavo et al., 2000). The $\mathrm{D}_{8901}$ strain used in this work is a Botuline strain that was first isolated from an animal by the Academy of Animal Husbandry and Veterinary Science of Qinghai in 1989 (Fig. 6). The obtained DNA encoded protein sequences were compared with sequences retrieved from GenBank database. The cloned DNA sequence was 99\% homologous with the type $\mathrm{D}$ botulinum toxin gene and lacked base deletions or additions. Our laboratory uses a homemade bidirectional dialyzer to stabilize the producing ability of the strain to 50 million MLD/ml. This lays the foundation for the largescale production of $\mathrm{D}$ type botulinum rodenticide.

The fastest growing application of botulinum toxin is in the field of cosmetic surgery. Botulinum preparations are used to effectively treat forehead wrinkles, crow's feet, and neck skin wrinkles (Sposito, 2002), as well as the benign hypertrophy of the mandibular angle of the masseter muscle (To, 2001). Studies have focused on the application of type $\mathrm{C}$ botulinum toxin in the control of grassland rodent damage in pastoral areas. The $\mathrm{D}_{8901}$ strain 
Table VI. Killing effect of different concentrations of type D botulinum toxin on zokors $\left(0.25 \mathbf{h m}^{2}\right)$.

\begin{tabular}{lllllll}
\hline Group & Repeat & $\begin{array}{l}\text { Mound number } \\
\text { before control }\end{array}$ & $\begin{array}{l}\text { New } \\
\text { mound number }\end{array}$ & $\begin{array}{l}\text { New Mound number } \\
\text { after control }\end{array}$ & $\begin{array}{l}\text { Efficiency } \\
\text { (\%) }\end{array}$ & $\begin{array}{l}\text { Mean efficiency } \\
\text { (\%) }\end{array}$ \\
\hline A & I & 87 & 13 & 0 & 100.0 & 89.83 \\
& II & 78 & 9 & 2 & 77.8 & \\
& III & 73 & 12 & 1 & 91.7 & \\
B & I & 57 & 8 & 1 & 87.5 & 80.06 \\
& II & 56 & 11 & 3 & 72.7 & \\
& III & 47 & 10 & 2 & 80.0 & \\
C & I & 69 & 9 & 1 & 88.9 & 89.13 \\
& II & 75 & 15 & 2 & 86.7 & \\
& III & 53 & 12 & 1 & 91.7 & \\
D & I & 50 & 8 & 1 & 87.5 & 87.73 \\
& II & 68 & 10 & 1 & 90.0 & \\
& III & 84 & 14 & 2 & 85.7 & \\
CK & I & 44 & 11 & 8 & 27.3 & 32.70 \\
& II & 39 & 8 & 5 & 37.5 & \\
& III & 56 & 12 & 8 & 33.3 & \\
\hline
\end{tabular}

A, granular bait; $\mathrm{B}, 0.10 \%$ group; $\mathrm{C}, 0.15 \%$ group; $\mathrm{D}, 0.02 \%$ group.

used in this work has strong toxin-producing capacity and higher safety of nontarget animals than type $\mathrm{C}$ botulinum toxin. For example, the minimum lethal dose of type $\mathrm{C}$ botulinum toxin in sheep is 0.214 million MLD/ $\mathrm{kg}$ weight and that of type D botulinum toxin is 4.88 million MLD/ $\mathrm{kg}$ weight. The difference between the $\mathrm{LD}_{50}$ of the two toxins in sheep is nearly 20 times. Thus, type $\mathrm{D}$ botulinum toxin is an effective rodenticide that is safe for nontarget animals.

The main species of rodents in Qinghai Province are plateau pikas and plateau zokors. The average area under threat of extensive rodent damage per year is 9.717 million $\mathrm{hm}^{2}$, and the area that is actually damaged by rodents is 7.3615 million $\mathrm{hm}^{2}$. Rodent damage results in the loss of more than 13.884 billion $\mathrm{kg}$ of fresh forage grass each year. Given that this volume of grass can be used to raise an additional 9.5096 million sheep, the ensuing economic loss caused by rodent damage reaches as high as 2.852 billion yuan. The area with rodent damage in Qinghai is 6.444 million $\mathrm{hm}^{2}$. The area of severely degraded grassland with vegetation coverage of less than $15 \%$ has reached 2.0921 $\mathrm{hm}^{2}$. Grasslands lose their biological barrier and water conservation ability with vegetation loss. Grassland loss severely degrades the ecological environment of Three Rivers Source and its branches. Therefore, the prevention and control of rodent damage in grasslands is necessary to protect grassland resources, animal husbandry production, and the environment ( $\mathrm{He}$ and $\mathrm{Hou}, 2014)$. The $\mathrm{LD}_{50}$ tests with intragastrically and orally administered type D botulinum toxin show that plateau pikas and plateau zokors are sensitive to type $\mathrm{D}$ botulinum toxin. The toxin is considered poisonous and conforms to the standard for rodenticides.

The chemical method and the biological method are commonly used for the large-scale prevention and control of rodent damage in pastoral areas. The biological method involves the use of natural predators, such as eagles and foxes, to prevent and control rodent populations. This method is suitable for small areas with low rodent damage but is unsuitable for large areas with intensive rodent damage. Chemical control is mainly used for the prevention and control of rodent damage domestically and internationally. The powerful rodenticides used in the past, including zinc phosphide, fluoroacetamide, and gliftor, are acute poisoning agents. They are characterized by strong toxicity and rapid action. However, all of these compounds exert secondary toxicity and kill nontarget animals, including natural rat enemies. Incidences of human and animal poisoning are also common (Wang et al., 1995; Wang et al., 1999). At the same time, rodents easily produce resistance and antifeedant responses to these chemicals. These effects decrease the control effect of the drugs and generate environmental pollution that severely damages grasslands. Hence, their use has been forbidden. We show that type D botulinum toxin is only safe for nontarget animals, including cattle and sheep, and 
for natural rat enemies, including eagles and G. barbatus. Moreover, the botulinum toxin is a large protein that is degraded under the action of natural environmental factors. The type $\mathrm{D}$ botulinum toxin is easily loses its poisonous under strong light, This characteristic indicates that the toxin can undergo photodecomposition and will not produce residual substances that persist in the environment (Wang et al.,1990).
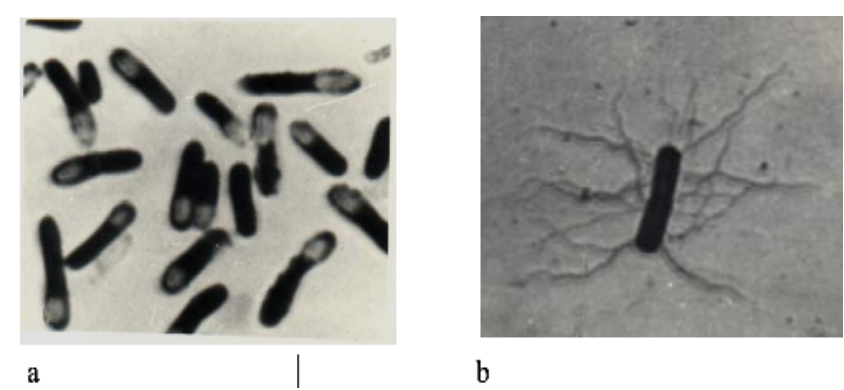

b

Fig. 6. Morphological characteristics (Micrograph (a) and electron micrograph (b)) of Clostridium botulinum.
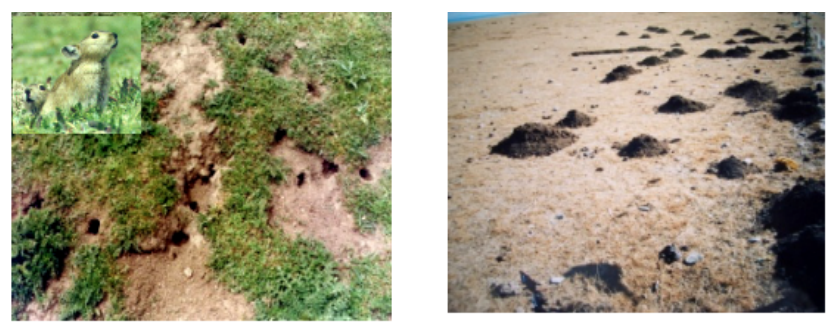

a $\mathrm{b}$

Fig. 7. (a), Grassland damage caused by plateau pika; (b), Mound caused by plateau zokor.

\section{Statement of conflict of interest}

The author declares there is no conflict of interest.

\section{REFERENCES}

Beeker Wegerich, P., Rauch, L. and Ruzicka, T., 2001. Botulinum toxin A in the therapy of mimic facial lines. Clin. exp. Dermatol., 26: 619. https://doi. org/10.1046/j.1365-2230.2001.00901.x

Cedric, W., Hanna, S. and Fabrizio, A., 2013. Validation of a realtime PCR based method for detection of Clostridium botulinum types C, D and their mosaic variants $\mathrm{C}-\mathrm{D}$ and $\mathrm{D}-\mathrm{C}$ in a multicenter collaborative trial. Anaerobe, 22: 31-37. https://doi.org/10.1016/j. anaerobe.2013.05.002

Christian, L., Géraldine, F. and Yves, M., 2013. A substrate sensor chip to assay the enzymatic activity of botulinum neurotoxin A. Biosen. Bioelectr., 49:
276-281. https://doi.org/10.1016/j.bios.2013.05.032

Dembek, Z.F., Smith, L.A. and Rusnak, J.M., 2007. Botulism: cause, effects, diagnosis, clinical and laboratory identiffication, and treatment modalities. Disaster Med. Pub. Hlth. Prep., 1:122-134. https:// doi.org/10.1097/DMP.0b013e318158c5fd

Gessler, F. and Böhnel, H., 1999. Production and purification of Clostridium botulinum type $\mathrm{C}$ and D neurotoxin. FEMS Immunol. Med. Microbiol., 24: 361-367. https://doi.org/10.1016/S09288244(99)00054-1

Hallis, B., James, B. A. and Shone, C. C., 1996. Development of novel assays for botulinum type $A$ and $B$ neurotoxins based on their endopeptidase activities. J . clin. Microbiol., 34: 1934-1938.

Hanson, M.A. and Stevens, R.C., 2000. Cocrystal structure of synaptobrevin-II bound to botulinum neurotoxin type B at angstrom resolution. Nat. Str. Biol., 7: 687-692.

He, X. and Hou X., 2014. Status and countermeasures of grassland rodent damage in Qinghai Province. $P l$. Protec, 7: 158- 159.

Kathryn Turton, Chaddock, J.A. and Acharya, K.R., 2002. Botulinum and tetanus neurotoxin:structure, function and therapeutic utility. Trends Biol. Sci., 27: 552558. https://doi.org/10.1016/S0968-0004(02)021771

Mingchun, W., Chongxuan, H. and Xuejun,Y., 1999. Study on the prevention and treatment of Gansu zokor by Kezhenxing. J. Nor. For. Univ., 14: 51- 56.

Peter, H.A., Sneath, Nicholoss, Mair, M., Elisabeth sharpe, John and Holt, G., 1986. Dergey's Manual of systematic Bocteriology, 2: 1157-1160.

Schiavo, G. and Matteoli, M., 2000. Montecucco C. neurotoxins affecting neuroexocytosis. Physiol. Rev., 80: 717. https://doi.org/10.1152/ physrev.2000.80.2.717

Smith, L.A. and Rusnak, J.M., 2007. Botulinum neurotoxin vaccines: past, present, and future. Crit. Rev. Immunol., 27: 303-318. https://doi.org/10.1615/ CritRevImmunol.v27.i4.20

Sposito, M.M., 2002. New indications for botulinum toxin type A in treating facial wrinkles of the mouth and neck. Aesthetic. Plast. Surg., 26: 89. https://doi. org/10.1007/s00266-002-1491-2

Tingzheng, W., Jingang, L. and Yue, Z., 1995. Analysis of the genesis of rodent fauna and squirrels in the Loess Plateau: Comprehensive management of squirrels in the loess plateau. Xi'an: Northwest University Press.

To, E.W., Ahuja, A.T. and Ho, W.S., 2001. A prospective study of the effect of botulinum toxin A on masseteric 
muscle hypertrophy with ultrasonographic and electromyographic measurement. Br. J. Plast. Surg., 54: 197. https://doi.org/10.1054/bjps.2000.3526

Wang, Z., Yang, X. and Zhou, Z., 1990. Preliminary report on demonstration and promotion of new technology of Clostridium botulinum toxin in rats. Sichuan Grassl., 3: 47- 49.

Wang, Y.C., 1987. Isolation and Identification of a D-type Clostridium botulinum. J. Microbiol., 27: 369.

Zhang, S.M., Li, G.Z., Yang, J.H. and Zhang, X.Y., 1990. Diagnosis of type D Botulism on sheep. Livest.
Poult. Infect. Dis., 6: 18.

Zhang, S.H., Ren, C. and Chen, G.M., 2001. Prevention and future plans on control of grassland rats in Qinghai Province. Qinghai Grass Indust., 18:55-59

Zhong, W. and Fan, N, 2002. Causes of grassland rats in China and their ecological control countermeasures. Bull. Biol., 37: 1- 5.

Zhou, L.-Z., Di-qian, L.I., Wang, X.-L. and Qiang, M.A., 2002. Sanjiangyuan reserve's rodent pests, their damage to frigid meadows and the control strategies. J. Anhui Univ. Nat. Sci. Edition., 26: 87-96. 